\title{
Sector -Wise Performance of FDI Equity Inflows in India
}

\author{
A. Muthusamy, S. Karthika
}

\begin{abstract}
Foreign Direct Investment (FDI) plays an important role in the development process of a country. It has the potential for contributing to the development through the transfer of financial resources, technology and innovative and improved management techniques along with raising productivity. Developing countries like India need substantial foreign inflows to achieve the required investment to accelerate economic growth and development. It can act as a catalyst for domestic industrial development. Further, it helps in speeding up economic activity and brings with it other scarce productive factors such as technical knowledge and managerial experience, which are equally essential for economic development. India has been the most significant beneficiary of remote direct interest in most of its various segments. It likewise assumes a significant job in the advancement of a nation. India is the biggest popularity based nation with the second biggest populace on the planet, with the standard of law and exceedingly instructed English talking work power, the nation is considered as a sheltered spot of assurance for outside financial specialists. The study covers the performance of FDI Equity inflows in India and the sector-wise performance of FDI Equity inflows in India. The samples of sector-wise FDI inflows in India are selected based on the convenient sampling method. A Sample of 10 sectors has been selected based on the availability of data. The inflow of FDI in the media transmission and Constrictions utilizing combined example t' test $P$ worth is 0.049 (Less than the estimation of 0.05). Henceforth we may accept the invalid speculation with $95 \%$ certainty. The Construction (foundation) exercises and Power utilizing combined example t' test. $P$ worth is 0.016 (Less than the estimation of 0.05). Subsequently, we may accept the invalid theory with $95 \%$ certainty.
\end{abstract}

Keywords : FDI Equity Inflows, Sector-wise, Relationship, Two-tail test.

\section{INTRODUCTION}

The historical backdrop of foreign investment in India can be followed back with the foundation of East India Company of Britain. English capital came into India during the pioneer time of Britain in India. Before freedom, the real measure of foreign investment originated from British companies. British organizations arrangement their units in mining segments and in those areas that suit their own financial and business premium. After the Second World War, Japanese organizations entered the Indian market and improved their exchange with India, yet the U.K. remained the most prevailing financial specialist in India. Remembering the national premiums, the arrangement creators structured the Foreign Direct Investment (FDI) strategy which points FDI as

Revised Manuscript Received on September 25, 2019

Dr.A.Muthusamy, Professor, Department of International Business, Alagappa University, Karaikudi.

S.Karthika, Full-Time Research Scholar, Department of Commerce,

Alagappa University, Karaikudi. a model for gaining cutting edge innovation and to activate foreign trade assets. Foreign Direct Investment (FDI) implies an investment through which the non-inhabitant speculator and foreign organization can begin another organization can get a viable offer in a current organization in India with the particular target of carrying on mechanical exercises or business in India. Foreign Direct Investment (FDI) is one of the most momentous improvements in the previous two decades. Foreign Direct Investment (FDI) in a more extensive sense is any long haul investment by a substance who dwells outside the host nation. Foreign substance puts cash in the host nation for a significant lot of time. They make an underlying investment before all else and thusly continue contributing as per the necessities and prerequisites of the host nation which could be as permission to better ( and less expensive) assets, right of section to a customer market or contact to ability explicit to the host nation - which results in the improvement of productivity. These long haul relationships recompense both the speculator just as the host nation. FDI investments are viewed as progressively advantageous for the host nation since it directly includes foundation advancement, increment work openings, improved strategic and store network framework and significantly more to include. It additionally acquires innovation move, upgraded administration and the executives rehearses. Foreign Direct Investment in any creating/immature nation can assume an imperative job in its economy; the reason being that there is a hole in the accessible assets or support and required assets and store. It is seen that FDI fills this hole by siphoning required store and assets and move of information and innovation too. This information sharing and innovation move upgrades proficient aptitudes, fortifies foundation, guarantee accessibility of global brands at doorstep, improve expectations for everyday comforts and make business. FDI is likewise considered as a dynamic instrument in accomplishing the independence of the nation all in all and certain areas specifically. Thinking about its enormous size of the market, sound financial approaches, and bounteous and talented HR, India has consistently been an appealing goal for foreign investment substances. Make in India is perhaps the most recent improvement in Foreign Direct Investment in India.

It is figured to pull in more investments from abroad to strengthen India's mechanical segment. The activity is expected to receive development, improve competency, and protect licensed innovation and shape the world's best assembling framework in the nation. 


\section{NEED AND IMPORTANCE OF THE STUDY}

India has been the most significant beneficiary of remote direct interest in most of its various segments. It likewise assumes a significant job in the advancement of a nation. India is the biggest popularity based nation with the second biggest populace on the planet, with the standard of law and exceedingly instructed English talking work power, the nation is considered as a sheltered spot of assurance for outside financial specialists. India is by all accounts experiencing a large group of willful limitations and issues concerning opening its business sectors too worldwide financial specialists by executing full-scale monetary changes. A portion of the significant hindrances for India's lackluster showing in the zone of FDI are political flimsiness, poor framework, confounding duty and levy arrangements, work laws, all around settled in debasement and administrative guidelines.

\section{OBJECTIVES OF THE STUDY}

The following are the objectives of the study

- To study the performance of FDI Equity inflows in India. - To study the sector-wise performance of FDI Equity inflows in India.

\section{REVIEW OF LITERATURE}

Abhishek Vijaykumar $\operatorname{Vyas(2015)}{ }^{{ }^{1}}$ Foreign Direct investment assumes a significant job in the improvement of the country. Some of the time locally accessible capital is lacking with the end goal of by and large improvement of the nation. Foreign capital is viewed as a method for filling in holes between household reserve funds and investment. India can pull in a lot bigger foreign investments than it has done previously. The examination features nation astute endorsements of FDI inflows to India and the FDI inflows in the various area for the period April 2000 to June 2015. The examination dependent on Secondary information which has been gathered through reports of the Ministry of Commerce and Industry, Department of Industrial Promotion and Policy, Government of India, Reserve Bank of India, and World Investment Report. The examination reasons that Mauritius rose as the most predominant wellspring of FDI contributing. It is because India has a Double Taxation Avoidance Agreement (DTAA) with Mauritius and the vast majority of the foreign nations like to put resources into the administration segment.

Priyanka Bedi and Ekta Kharbanda (2014) ${ }^{2}$ Nations around the globe both created and creating, are taking coordinated endeavors in an offer to pull in more noteworthy progressions of FDI into their economies. The Indian government is investigating every possibility in its endeavor to pull in more noteworthy FDI streams into India. In any case, in spite of the way that India offers a huge potential market, has a pool of capable, taught and talented workforce, has generally low work expenses and liberal popularity based political structure, the FDI inflows into India have stayed low in contrast with other developing markets. In this scenery, this paper looks to investigate the status of FDI inflows into India and distinguish the issues and issues that have made India a less appealing goal when contrasted with different countries. The investigation is exploratory and auxiliary information has been gathered from different reports and productions of Government of India, World Bank, OECD, World Economic discussion and so on. The investigation will empower us to get knowledge on the means that the Indian government can take and furthermore a few exercises that India can gain from nations like China to build the allure of India as an FDI goal. Debabrata Sutradhar (2014) ${ }^{3}$ In the contemporary globalized economy, the administration area draws in the real portion of Foreign Direct Investment (FDI) on the planet. India being a piece of this wonder likewise pulls in the greater part of its FDI in the administration division. The present paper features the pattern in FDI development on the planet by and large and India specifically. Further, it audits the FDI arrangement in India in the post changed period. The development of FDI in administration division might be ascribed to the changing example of worldwide FDI and furthermore, the progression and globalization approach sought after by India. Since 2000, the high inflow of FDI has brought about the development of new administrations viz., money related and non-budgetary administrations, media transmission, PC programming and equipment, inn and the travel industry, development exercises, and land. The development of the administrations' area had prompted the development of fare of administrations from India which currently accounts for most of the fare from the nation.

Sharma Reetu and Khurana Nikitati $(\mathbf{2 0 1 3})^{4}$ India has been the most significant beneficiary of foreign direct investment in most of its various segments. It likewise assumes a significant job in the improvement of a nation. The goal of the present paper is to give a wide framework for foreign direct investment with the setting of various divisions. It likewise calls attention to the division shrewd conveyance of FDI inflow to think about which has worried about the central offer. The present investigation depends on auxiliary information and the optional information has been gathered from various sources i.e., reality sheets on foreign direct investment, Annual reports of Reserve Bank of India, the site of UNCTAD and various diaries. The investigation utilized a piece of information from 1991-92 to 2011-2012 (post-progression period). The present paper additionally talks about the different issues about foreign direct investment and proposes a few proposals for the equivalent. The present examination found that the Indian economy is generally founded on farming. Thus, there is a most significant extent of agribusiness administrations. Consequently, the foreign direct investment in this area ought to be energized

Nilofer Hussaini. N H (2011) ${ }^{\mathbf{5}}$ Foreign Direct Investment in the previous years has produced a ton of elation. It is said that the "solid basis" of the economy supported by the changed government approach has prompted the blast of FDI inflow in India. This paper features the fundamental monetary determinants of FDI inflow in India and there critical 
relationship with the genuine FDI inflows. The paper additionally inspects the division astute pattern in Foreign Direct Investment (FDI) inflow into India during post-progression period and the ongoing pattern of India as a falling goal for FDI. The timeframe with the end goal of study ranges from 1991 to 2009 constraining the main 10 areas of the Indian economy. It is unequivocally had faith in the examination that FDI inflow throughout the decades has demonstrated a temperamental and fluctuating pattern in different divisions of the Indian economy. FDI inflow in India is observed to be very related with the monetary elements thought about and it is to India's greatest advantage to keep on boosting foreign investment by changing standards on value tops, investment surveys and different arrangements that have hindered India's capacity to draw in considerably increasingly foreign investment over the ongoing years.

\section{METHODOLOGY OF THE STUDY}

The study is based on the Analytical in nature and the present study is solely founded on auxiliary information and is done to look at and assess the sector-wise performance of equity inflows. With the end goal of concentrate optional information and reports are been utilized, which are gathered from distributed reports of countries chief affordable and business organizations, magazines, RBI yearly report, DIPP reports and warnings, investigate articles and monetary foundations sites.

Table 1:Sector-wise performance of FDI equity inflows in India during the period 2016-2017 to 2018-2019 (Amount in US \$ Million)

\section{SAMPLE DESIGN OF THE STUDY}

The samples of sector-wise FDI inflows in India are selected based on the convenient sampling method. A Sample of 10 sectors has been selected based on the availability of data. The following have been selected for the sector-wise to the study

1. Services Sector

2. Computer Software \& Hardware

3. Telecommunications

4. Construction Development

5. Trading

6. Automobile Industry

7. Chemicals (Other Than Fertilizers)

8. Drugs \& Pharmaceuticals

9. Construction (Infrastructure) Activities 10. Power

\section{PERIOD OF THE STUDY}

The present study covers a period of three years, taking from 2016- 2017 to 2018-2019.

\section{DATA ANALYSIS AND INTERPRETATION}

The following table shows the FDI Equity inflows during the year from 2016-2017 to 2018-2019. Table 1 shows the total equity inflows and CAGR

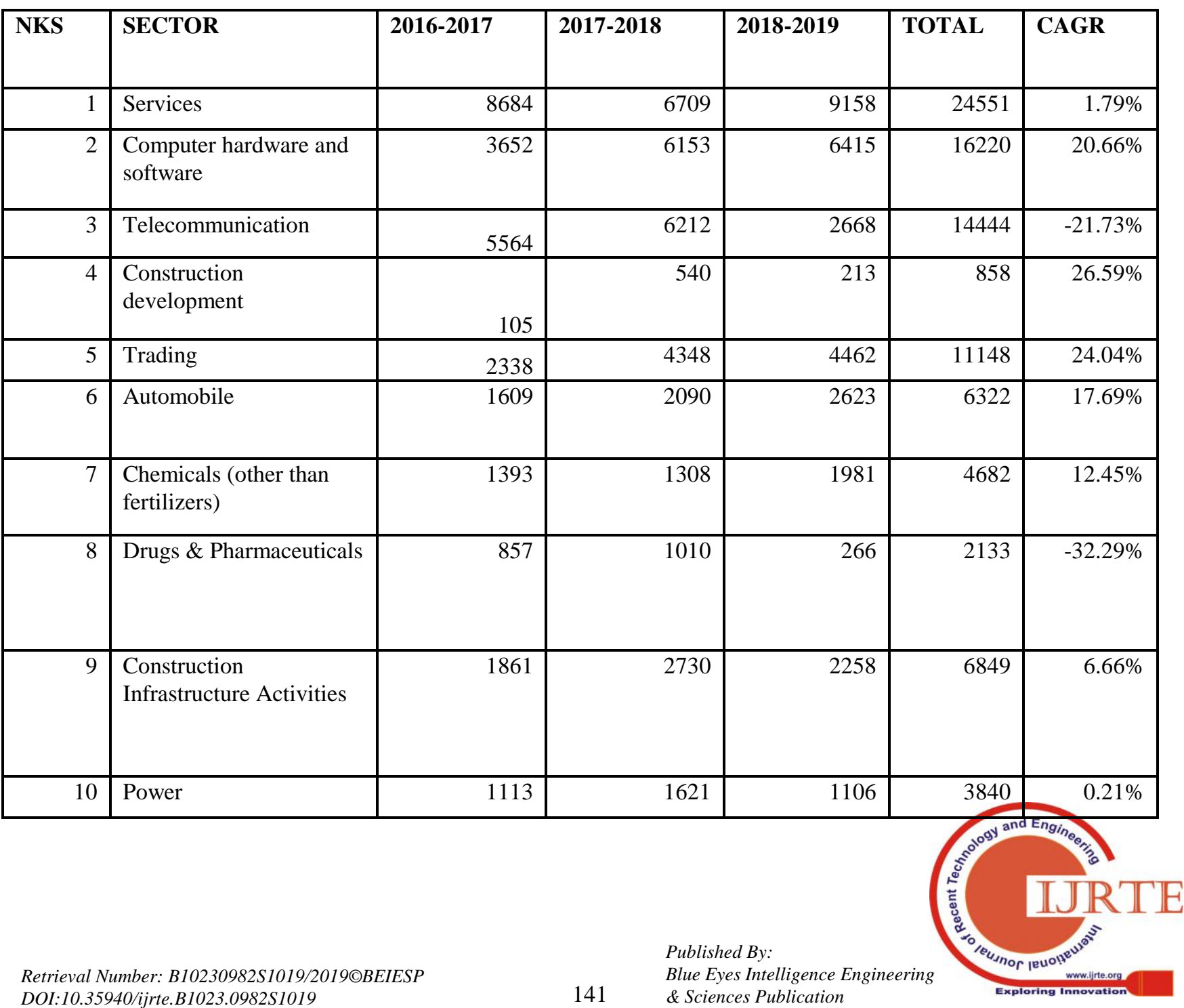




\section{INTERPRETATION}

The following table1 gives the amount of FDI inflows from 2016-2017 to 2018-2019 for the construction development sector has the highest compound annual growth rate of 26.59 percent FDI equity inflow in India during the study period. It gives the relevant details whether the sector-wise performance of FDI Equity inflow differed across the three years, the two-tail test was used.

t - TEST - THE SECTORS ATTRACTING HIGHEST FDI EQUITY INFLOWS
1. Null Hypothesis: There is no significant relationship between the services-sector and computer software \& hardware of Sector FDI Equity inflows.

The following table 2 gives the particulars of the services sector and computer software \& hardware of Sector FDI Equity inflows during the period from 2016-2017 to 2018-2019.

Table 2:Paired Samples Test

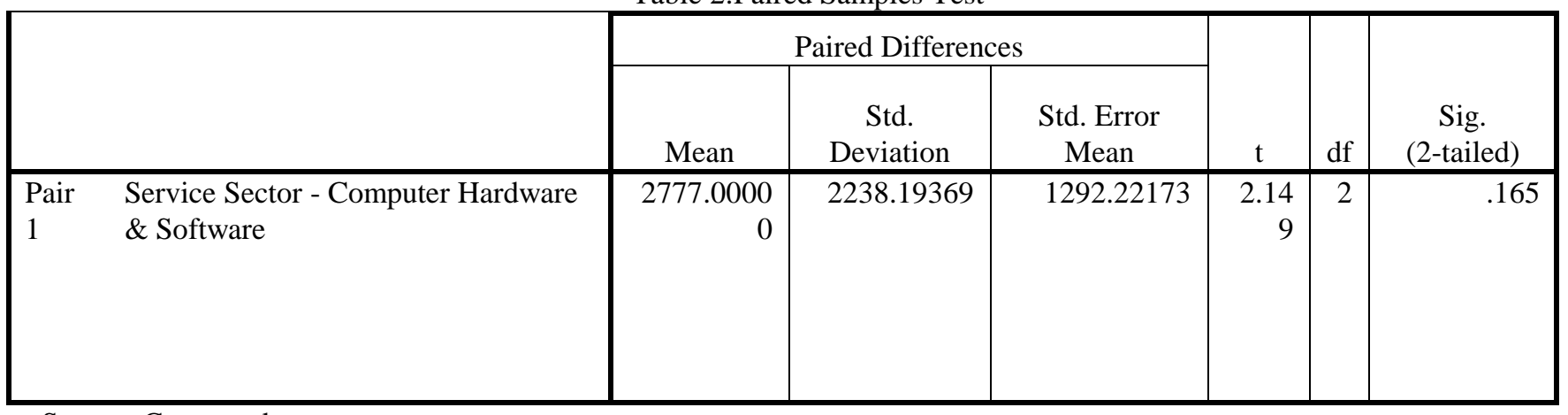

Source: Computed

\section{INTERPRETATION}

Compared to the services sector and computer software \& hardware using paired sample t-test from the table no 2 it shows that the calculated value of ' $t$ ' is 2.149 for degrees of freedom $=2$, and at $5 \%$ level of significance of the two-tail test. P-value is 0.165 (Greater than the value of 0.05 ). Hence we may reject the null hypothesis with $95 \%$ confidence. It is clear that the calculated value of ' $t$ ' is greater than that of the table. It reveals that there is no significant relationship between the services sector and computer software \& hardware of Sector FDI Equity inflows.
2. Null Hypothesis: There is no significant relationship between telecommunication and Constrictions of Sector FDI Equity inflows.

The following table 3 gives the particulars of telecommunication and Constrictions of Sector FDI Equity inflows during the period from 2016-2017 to 2018-2019.

Table 3: Paired Samples Test

\begin{tabular}{|c|c|c|c|c|c|c|c|}
\hline & & \multicolumn{3}{|c|}{ Paired Differences } & \multirow[b]{2}{*}{$\mathrm{t}$} & \multirow[b]{2}{*}{ df } & \multirow[b]{2}{*}{$\begin{array}{c}\text { Sig. } \\
\text { (2-tailed) }\end{array}$} \\
\hline & & Mean & Std. Deviation & $\begin{array}{l}\text { Std. Error } \\
\text { Mean }\end{array}$ & & & \\
\hline $\begin{array}{l}\text { Pair } \\
2\end{array}$ & $\begin{array}{l}\text { Telecommunication - } \\
\text { Construction }\end{array}$ & 4528.66667 & 1799.00315 & 1038.65495 & 4.360 & 2 & .049 \\
\hline
\end{tabular}

Source: Computed

\section{INTERPRETATION}

Compared to the telecommunication and Constrictions using paired sample t-test from the table no 3 it shows that the calculated value of ' $t$ ' is 4.360 for degrees of freedom $=2$, and at $5 \%$ level of significance of the two-tail test. P-value is 0.049 (Less than the value of 0.05). Hence we may Accept the null hypothesis with $95 \%$ confidence. It is clear that the calculated value of ' $t$ ' is less than that of the table. It reveals that there is a significant relationship between Germany and Cyprus FDI.
3. Null Hypothesis: There is no significant relationship between the Trading and Auto Mobile Industry of Sector FDI Equity inflows.

The following table 4 gives the particulars of Trading and Auto Mobile Industry of Sector FDI Equity inflows during the period from 2016-2017 to 2018-2019. 
Table 4:Paired Samples Test

\begin{tabular}{|c|c|c|c|c|c|c|c|}
\hline & \multicolumn{3}{|c|}{ Paired Differences } & \multirow[b]{2}{*}{$\mathrm{t}$} & \multirow[b]{2}{*}{ df } & \multirow[b]{2}{*}{$\begin{array}{c}\text { Sig. } \\
\text { (2-tailed) }\end{array}$} \\
\hline & & Mean & Std. Deviation & $\begin{array}{c}\text { Std. Error } \\
\text { Mean }\end{array}$ & & & \\
\hline Pair 3 & $\begin{array}{l}\text { Trading - the } \\
\text { Automobile } \\
\text { industry }\end{array}$ & 1608.66667 & 790.09514 & 456.16164 & 3.527 & 2 & .072 \\
\hline
\end{tabular}

Source: Computed

\section{INTERPRETATION}

Compared to the services sector and computer software \& hardware using paired sample t-test from the table no 4 it shows that the calculated value of ' $\mathrm{t}$ ' is 3.527 for degrees of freedom $=2$, and at $5 \%$ level of significance of the two-tail test. $\mathrm{P}$-value is 0.072 (Greater than the value of 0.05 ). Hence we may reject the null hypothesis with $95 \%$ confidence. It is clear that the calculated value of ' $t$ ' is greater than that of the table. It reveals that there is no significant relationship between the Trading and Auto Mobile Industry of Sector FDI Equity inflows.
4. Null Hypothesis: There is no significant relationship between Chemicals (other than fertilizers) - Drugs \& Pharmaceuticals of Sector FDI Equity inflows.

The following table 5 gives the particulars of Chemicals (other than fertilizers) - Drugs \& Pharmaceuticals of Sector FDI Equity inflows during the period from 2016-2017 to 2018-2019.

Table 5:Paired Samples Test

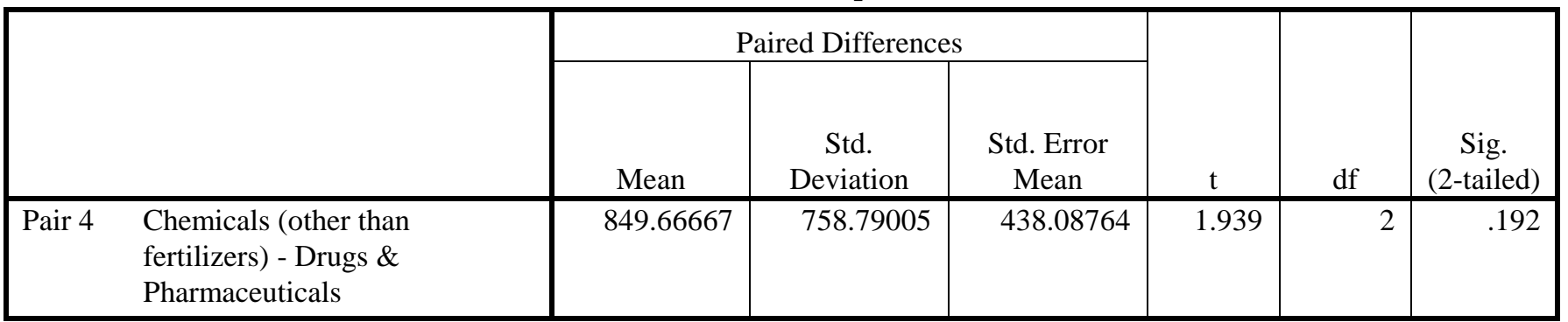

Source: Computed

\section{INTERPRETATION}

Compared to the Chemicals (other than fertilizers) - Drugs \& Pharmaceuticals using paired sample t-test from the table no 5 it shows that the calculated value of ' $t$ ' is 1.939 for degrees of freedom $=2$, and at $5 \%$ level of significance of the two-tail test. P-value is 0.192 (Greater than the value of 0.05). Hence we may reject the null hypothesis with $95 \%$ confidence. The calculated value of' is greater than that of the table. It reveals that there is no significant relationship between the Chemicals (other than fertilizers) - Drugs \& Pharmaceuticals of Sector FDI Equity inflows.
5. Null Hypothesis: There is no significant relationship between Construction (infrastructure) activities and the Power of Sector FDI Equity inflows.

The following table 6 gives the particulars of Construction (infrastructure) activities and Power of Sector FDI Equity inflows during the period from 2016-2017 to 2018-2019.

Table 6:Paired Samples Test

\begin{tabular}{|c|c|c|c|c|c|c|c|}
\hline & & \multicolumn{3}{|c|}{ Paired Differences } & \multirow[b]{2}{*}{$\mathrm{t}$} & \multirow[b]{2}{*}{ df } & \multirow[b]{2}{*}{$\begin{array}{c}\text { Sig. } \\
\text { (2-tailed) }\end{array}$} \\
\hline & & Mean & $\begin{array}{c}\text { Std. } \\
\text { Deviation }\end{array}$ & $\begin{array}{l}\text { Std. Error } \\
\text { Mean }\end{array}$ & & & \\
\hline Pair 5 & $\begin{array}{l}\text { Construction } \\
\text { (infrastructure) activities } \\
\text { - Power }\end{array}$ & 1003.00000 & 221.88060 & 128.10282 & 7.830 & 2 & .016 \\
\hline
\end{tabular}

Source: Computed

\section{INTERPRETATION}

Compared to the Construction (infrastructure) activities and Power using paired sample t-test from the table no 6 it shows that the calculated value of' is 7.830 for degrees of freedom $=$
2 and at $5 \%$ level of significance of the two-tail test. P-value is 0.016 (Less than the value of $0.05)$. Hence we may accept the null hypothesis with $95 \%$ 
confidence. It is clear that the calculated value of' is less than that of the table. It reveals that there is a significant relationship between the Construction (infrastructure) activities and Power FDI.

\section{CONCLUSION}

FDI in India has a critical job in the monetary development and improvement of India. FDI in India in different parts can achieve supported monetary development and advancement through the production of employments, an extension of existing assembling enterprises. The study covers only the performance of FDI Equity inflows in India and the sector-wise performance of FDI Equity inflows in India. The samples of sector-wise FDI inflows in India are selected based on the convenient sampling method. The study covers the only Sample of 10 sectors that have been selected based on the availability of data. The present study covers an only period of three years, taking from 2016- 2017 to 2018-2019. The inflow of FDI in the media transmission and Constrictions utilizing combined example t-test $\mathrm{P}$ worth is 0.049 (Less than the estimation of 0.05). Henceforth we may accept the invalid speculation with $95 \%$ certainty. The Construction (foundation) exercises and Power utilizing combined example t-test. $\mathrm{P}$ worth is 0.016 (Less than the estimation of 0.05). Subsequently, we may accept the invalid theory with $95 \%$ certainty.

\section{ACKNOWLEDGEMENT}

The research paper funded by RUSA (Rashtriya Uchchatar Shiksha Abhiyan) phase 2.0 scheme by ministry of Human Resource Development (MHRD), India. The authors are filled with appreciation to the unknown referees of journal for their useful suggestions to process the paper quality.

\section{REFERENCES}

1. www.ibef.com

2. www.dipp.nic.in

3. www.data.gov.com

4. www.fdi.gov.in

5. Priyanka Bedi and Ekta Kharbanda "Analysis of Inflows of Foreign Direct Investment in India- Problems and Challenges" Global Journal of Finance and Management. ISSN 0975-6477 Volume 6, Number 7 (2014), pp. 675-684

6. Abhishek Vijaykumar Vyas "An Analytical Study of FDI in India" International Journal of Scientific and Research Publications, Volume 5 , Issue 10 . 